\title{
A modernidade e a ruptura transatlântica: Uma reflexão sobre o comércio de escravos
}

Modernity and the Transatlantic Rupture: A Meditation on the Slave Trade La modernité et la rupture transatlantique : une réflexion sur le commerce des esclaves

\section{Houston Baker Jr}

Tradutor. João Paulo Moreira

\section{OpenEdition}

\section{Journals}

\section{Edição electrónica}

URL: http://journals.openedition.org/rccs/927

DOI: $10.4000 /$ rccs.927

ISSN: 2182-7435

\section{Editora}

Centro de Estudos Sociais da Universidade de Coimbra

\section{Edição impressa}

Data de publição: 1 Junho 2006

Paginação: 49-64

ISSN: 0254-1106

Refêrencia eletrónica

Houston Baker Jr, « A modernidade e a ruptura transatlântica: Uma reflexão sobre o comércio de escravos », Revista Crítica de Ciências Sociais [Online], 74 | 2006, colocado online no dia 01 dezembro 2012, criado a 21 abril 2019. URL : http://journals.openedition.org/rccs/927 ; DOI : 10.4000/rccs.927 


\title{
A modernidade e a ruptura transatlântica: Uma reflexão sobre o comércio de escravos
}

\begin{abstract}
A aplicabilidade global da modernidade tem a sua marca mais relevante no Tráfico de Escravos Transatlântico, em que milhões de africanos foram deportados para o "Novo Mundo". Analisar a economia do tráfico e as suas implicações diaspóricas resulta no reconhecimento da importância do açúcar como mercadoria e da plantação como meio de produção. Partindo de um prelúdio rememorativo centrado na cidade de Coimbra em Portugal, a análise inclui uma explanação da escravatura nas colónias da América do Norte e das suas implicações hoje para o problema da raça nos Estados Unidos.
\end{abstract}

Há um par de anos, pessoa amiga lembrou-se de apelar ao modesto capital artístico amealhado na minha conta de poeta negro para convencer os seus colegas a convidar-me a participar no V Encontro Internacional de Poetas, em Coimbra. Não eram ilimitados os fundos ao dispor dos organizadores, pelo que tive que decidir se valeria a pena usar o meu orçamento pessoal para me deslocar ao estrangeiro. Desde logo me senti fortemente tentado a aceitar, visto estarem anunciados poetas famosos como Charles Bernstein e Seamus Heaney. Mas e o dinheiro? De novo ecoaram em mim as palavras que o meu pai me dissera muitos anos antes, quando me dirigiram um convite para uma estada em Edimburgo a fim de ali desenvolver o meu trabalho académico: "Isso não, meu filho, nós não desaproveitamos oportunidades dessas!" Pus mentalmente entre parênteses a questão do dinheiro e aceitei o convite para ir a Portugal. Mal fazia ideia, na altura, de que iria conhecer gente tão cativante, deparar com palavras e apresentações tão prodigiosas, e, para além de tudo isso, granjear capital teórico académico suficiente para, volvido precisamente um ano, ser convidado para um espantoso congresso português sobre "Modernismos".

No decurso do congresso, os sons, as texturas e os ritmos da Universidade de Coimbra (a mais antiga de Portugal, fundada no século XIII) e a cultura do país ficaram para mim definitivamente ligados ao modernismo e à poesia do Sul. A convergência das minhas duas visitas ao estrangeiro conduziu, das formas mais inesperadas (e certamente previsíveis para o meu pai), a 
uma compreensão mais profunda de como o Sul se tornou o fecundante negro e sujo Sul que é hoje. O meu encantamento com os colegas portugueses e o modo como estes me aceitaram - principalmente através do nosso envolvimento comum com a "modernidade", no contexto do congresso proporcionou-me a grata oportunidade de reflectir sobre as dimensões globais de uma região que é imperioso que seja mais amplamente (e porventura mais "impulsivamente") cantada pelos investigadores das gerações de hoje. "Contar o Sul”, como se lê num bem conhecido episódio da ficção faulkneriana, é contar uma ruptura - uma ruptura transatlântica da modernidade, na qual Portugal desempenhou um papel nada despiciendo.

Dou aqui conta de uma versão da história dessa ruptura e das suas implicações meridionais. Mais do que um mero "testemunho pessoal negro", tal afigura-se-me, de algum modo, como um prelúdio necessário a um entendimento adequado do que é o Sul. E é, sem qualquer dúvida, um prelúdio necessário a uma leitura criteriosamente informada de autores como William Faulkner e outros escritores "sulistas". Começo, por isso, esta minha história no presente do indicativo.

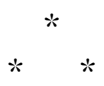

Regressei a Coimbra, uma pequena cidade situada a duas horas de viagem de Lisboa. Estive aqui há apenas um ano por ocasião do V Encontro Internacional de Poetas. (Os meus generosos anfitriões concederam-me a oportunidade de vestir a pele de poeta, fazendo uma leitura da minha poesia na última noite do Encontro, num esplêndido teatro localizado na cidade universitária.) Estamos, agora, em Junho de 2005. O calor das pedras irregulares da calçada infiltra-se pelas solas finas dos meus sapatos. O rio Mondego e a sua ponte mantêm o brilho prateado que deles guardei na memória. Majestosas fachadas do Velho Mundo sugerem épocas há muito passadas. Em Coimbra, o tempo lento exibe as cores da milenar glória mediterrânica.

O prato nacional dos Portugueses é o bacalhau, geralmente acompanhado com broa de milho. É delicioso, e contudo singelo - uma representação cultural de tipo semelhante ao peixe salgado com ackee da Jamaica, ou ao frango caseiro frito dos Afro-americanos, servido com ervas. Na sua simplicidade, comida assim faz-me lembrar uma frase de uma das peças de teatro alusivas ao dia de Acção de Graças, em que o nosso filho entrou na escola primária: "Somos Peregrinos; aquilo que temos nos basta". É claro que este alicerce de pragmatismo vinha revestido de uma saudável camada de hipocrisia. Uma vez terminado o festim amistoso entre Índios e Peregri- 
nos, estes apressaram-se a apropriar-se de praticamente tudo o que era pertença das populações nativas - incluindo a terra em que viviam.

A História de Portugal tem o seu quinhão pouco recomendável no que se refere àquilo a que, em tempos mais recentes, se veio a chamar "o Outro" (do latim alteru - o segundo, ou o outro de uma enumeração -, e que, no caso do inglês, nos remete para a palavra alemã anders - "anterior", "fora", "o não-eu”). No século XIV, Portugal era uma nação de marinheiros devotada a Deus e ao ouro (se bem que nem sempre por esta ordem). Os seus intrépidos navegadores atravessaram largos oceanos. Na verdade, foi o príncipe português Infante Dom Henrique quem custeou as embarcações que iriam conseguir dobrar pela primeira vez o cabo Bojador, possibilitando a navegação para além da costa da Guiné (na África Ocidental). Daí prosseguiriam até Cabo Verde. Entre os fartos proventos comerciais dessas viagens contavam-se "cativos" (escravos africanos), ouro, e terras e ilhas fortificadas. Havia ainda o açúcar.

Para Dom Henrique, a ideia de um empreendimento oceânico lucrativo para o seu país encontrava justificação sobretudo na sua portuguesa noção do "outro". Foi seu expresso desejo "acrescentar em a santa fé de nosso senhor Jesus Cristo, e trazer a ela todalas almas que se quisessem salvar" (Zurara, 1937: 62). É de supor que, para as almas dos africanos, tal salvação haveria de ter lugar algures fora de Portugal continental. Talvez no Brasil? Porque a verdade é que em Coimbra (ou mesmo em Lisboa) afiguraram-se-me escassos, durante as minhas duas visitas, os sinais de uma presença portuguesa negra.

Nesta última viagem, eu e a minha mulher contratámos um taxista para um curto passeio pelo interior e até Fátima. A dada altura perguntei-lhe: "Onde estão os negros de Portugal?" Ao que ele respondeu: "Estão nas cidades, que é onde estão os empregos. No campo não arranjam trabalho". Mas no dia seguinte, em Lisboa, também não havia muito negro à vista. Que acontecera, então, aos “cativos” do Infante? É de desconfiar que foram, na sua maior parte, vendidos e despachados por barco - com a bênção dos Santos Padres - para a "salvação" da escravatura nas Índias Ocidentais, também chamadas ilhas do açúcar. Contudo, esta parte de Coimbra já pertence ao passado, em suave harmonia com os muros vetustos e com as já longínquas memórias da cidade.

Passeando, hoje, pela zona ribeirinha, recentemente alvo de intervenções no plano económico e arquitectónico, são visíveis traços idênticos aos que, um pouco por todo o mundo, assinalam comunidades luxuosas junto às praias e à beira-rio. Cafés, esplanadas, discotecas, estatuária e museus alusivos ao oceano, bancos de pedra, vendedores ambulantes, placas comemo- 
rativas, vistas magníficas sobre o mar com o pôr-do-sol em fundo. A marginal da cidade de Coimbra, agora revitalizada e segura para a prática do turismo, é a prova do orgulho português na modernização. Principalmente quando os nossos simpáticos acompanhantes não se cansam de sublinhar que "Há uns anos apenas, nem sequer durante o dia se podia aqui andar em segurança!".

A Universidade de Coimbra foi fundada em 1290, o que faz da cidade uma espécie de Oxford portuguesa e sem dúvida a mais antiga sede do saber no país. Por trás dos impressionantes portões de ferro sucedem-se os grupos de turistas em visita à parte histórica da Universidade, enquanto mesmo ao lado se erguem os modernos edifícios de várias faculdade, a que não faltam cantinas e auditórios de mobiliário vistoso e sólido. No corpo docente abundam académicos cheios de erudição, cosmopolitas e "modernos" em todos os sentidos que se possa imaginar, visivelmente capazes de, sem esforço, empreender qualquer tipo de trabalho com aplomb intelectual e a mais amistosa das disposições.

A Universidade e o seu corpo de docentes revelaram-se anfitriões inexcedíveis por ocasião dos Modernismos, o colóquio de dois dias que me levou de regresso a Coimbra. Coube-me a mim a conferência de encerramento do colóquio - uma iniciativa destinada a assinalar a conclusão de um projecto de investigação colectivo levado a efeito pelo Centro de Estudos Sociais da Universidade e intitulado Memória, Violência e Identidade: Novas Perspectivas Comparadas sobre o Modernismo.

O que é, o que foi, e o que será no futuro o modernismo? Eis as perguntas que orientaram o estudo da equipa de investigadores, acrescidas e reforçadas por uma quarta questão: "Porquê modernismos", no plural? Nos trabalhos intervieram participantes vindos da Holanda e dos Estados Unidos da América, para além de um conjunto de investigadores de primeira água, oriundos das instituições de ensino superior e centros de investigação do país organizador.

O meu primeiro impulso, quando convidado, foi pensar: "Tenho que falar do Sul”. Não pensei, nessa altura, em sonantes termos pós-modernos, característicos de uma certa sensibilidade política ou ambientalista que divide o mundo em dois, com um "Sul" grosseiramente subdesenvolvido a viver sob a sombra imponente de um "Norte" dotado de abundantes recursos. Não, a minha resposta foi antes no exacto sentido daqueles estados que, no mapa dos EUA, se situam abaixo da linha Mason-Dixon ${ }^{1}$.

\footnotetext{
${ }^{1}$ Linha imaginária de separação entre os estados do Norte e do Sul, mais ou menos coincidente com o limite meridional do estado da Pensilvânia. [N. do T.]
} 
Porque os condados, as cidades, os subúrbios e as comunidades muradas de toda essa região pegaram em melodias e sentimentalismos como os de "The Old Folks at Home" ("Em casa os Velhotes") e transformaram-nos radicalmente nos versos rápidos como metralha e na brilhante batida do "hip hop" do Sul Sujo - o "Dirty South" - de que é exemplo a canção 'Player's Ball', do grupo OutKast. Andre Benjamin (Andre 3000) e Antwan Patton (Big Boi), membros do duo The OutKast, criaram uma linguagem poética áspera que reflecte por inteiro o neocosmopolitismo de capitais sulistas norte-americanas como Columbia, Baton Rouge, Nashville e Atlanta. A revista universitária American Literature (de que sou responsável) tem presentemente em preparação um número especial intitulado "O Sul Global". E, de facto, tendo passado os olhos pelo folheto de anúncio da sua publicação, dou-me conta de que, hoje mais do que nunca, o Sul constitui uma realidade demográfica moderna e pujante, em vias de se transformar, gradual mas decididamente, na sede de inúmeras empresas multinacionais, um lugar onde o preço dos terrenos frente ao mar ou em retiros de montanha está a subir em flecha, e que atrai às dezenas de milhar os ianques que, vindos do Norte, para aqui afluem em voluntário expatriamento. Obviamente que o Sul também se está a confrontar com os obscuros dilemas da globalização, como sejam a tão discutida questão da imigração mexicana e centro-americana. A esta acresce um evangelismo religioso de tipo novo e profundamente problemático, que anda a par não só do tradicional e zeloso apego desta região à pena capital, mas também de um complexo industrial prisional privado em plena expansão. Além disso, há ainda, como é sabido, a sempre bicuda questão da raça, um problema não-biodegradável que obstinadamente permanece por resolver. Nos vocabulários dos EUA, falar do "problema da raça" é o mesmo que evocar uma região geográfica muito precisa: $o$ Sul.

O meu objectivo para o colóquio sobre os Modernismos foi, então, juntar as geografias de Portugal e da sulista Birmingham, que é como quem diz, associar os propósitos salvacionistas do bom príncipe D. Henrique e do chamado "Acordo Mediterrânico" (que definirei adiante) à paisagem que se estende para baixo da Mason Dixon, com os seus fartos deltas, os férteis arrozais, os campos ondulantes de níveo algodão, e a cana do açúcar, afiada e cortante como navalhas.

Mas como transformar a minha estada em Coimbra em algo que, falando do Sul, não só fosse relevante como também correspondesse ao que se espera de uma conferência de fundo?

Quis o destino que Paula Mesquita, uma doutoranda presente entre os participantes, fosse apresentar no primeiro dia uma comunicação intitulada 
'Playing the Part in the War Theater: Gender as a Battlefield in Cather and Faulkner' ('Desempenhando o Papel no Teatro de Guerra: a diferença sexual como campo de batalha em Cather e Faulkner'). Portanto, era assente que o "s" no final de Modernismos também abrangia Faulkner. Em Coimbra, o Sul estava sempre já devidamente posicionado. Acontece que Paula Mesquita estivera na "Yoknapatawpha Conference" em Oxford, no Mississipi, em 2003, altura em que me coube fazer a conferência de abertura do congresso. O trabalho que vem levando a cabo é de uma estupenda originalidade, e conversámos brevemente sobre dois autores sulistas com grande aceitação fora dos Estados Unidos: William Faulkner e Richard Wright. Sem dúvida que o Sul está de novo em ascensão nos estudos literários e culturais europeus, e julgo que por razões globais.

Dados os moldes transnacionais do colóquio, pareceu-me que não haveria melhor maneira de enquadrar toda a discussão sobre a ruptura do modernismo e o Sul dos Estados Unidos de hoje do que tomar como referência à diáspora negra. Fazê-lo equivale a trazer à mente correntes transatlânticas que, ao longo destes últimos anos, têm passado pela música "pop", pelo cinema e por outras formas de expressão evocativas da "negritude em movimento". Comecei a minha comunicação com uma vídeo-montagem da autoria da minha colega Heather Russell Andrade, da Florida International University, e constituída por cenas dos filmes Amistad, Rosewood ${ }^{2}$, Sankofa, e Life and Debt (este último - "Vida e Dívidas" - um brilhante documentário sobre as "modernas" economias jamaicanas). As imagens foram passadas ao som de "Redemption Song", de Robert Nesta (Bob) Marley.

Um sítio da "Web", citando a obra de Timothy White, Catch A Fire: The Life of Bob Marley ("Agarra o lume: Vida de Bob Marley"), refere que a composição "Redemption Song" é "[...] um espiritual acústico plangente, próximo do estilo de Dylan, e desprovido de qualquer vestígio de reggae. Quando a cantava, [Marley] ficava com uma expressão de menino a brincar, mas a voz trazia em si a autoridade de um patriarca bíblico [...] é como que a declaração final de uma carreira, o balanço de todos os temas e do pensamento que a forjaram [...] (Marley, 2002). Eis a letra deste produto-profecia de Bob Marley:

Velhos piratas sim rouba eu

Vende eu aos barcos de mercadores

Logo depois me leva do

Fosso sem fundo

${ }_{2}$ Título no circuito comercial, em Portugal, Rosewood: O Massacre. [N. do T.] 
Mas minha mão a mão

Do todo-poderoso fez forte

Avancemos nesta geração em triunfo

Tudo o que sempre tive foram canções de liberdade

Vinde ajudar a cantar estas canções de liberdade

Porque tudo o que sempe tive canções de redenção, canções de redenção

Emancipai-vos da escravidão mental

Só nós podemos libertar nossas mentes

Não temais a energia atómica

Pois nenhum deles conseguirá parar o tempo

Até quando vão eles matar nossos profetas

E nós parados a assistir

Há quem diga que faz parte

Temos que cumprir o escrito

Vinde ajudar a cantar, estas canções de liberdade

Porque tudo o que sempe tive, canções de redenção, canções de redenção

Vinde ajudar a cantar, estas canções de liberdade

Porque tudo o que sempe tive, canções de redenção

Tudo o que sempe tive, canções de redenção

Estas canções de liberdade, canções de liberdade.

E assim, num sufocante dia de sol em Portugal, comecei a minha jornada de conferencista principal a caminho de um modernismo negro concreto que ainda busca a sua redenção, principalmente no Sul contemporâneo. Que melhor sítio para começar do que as próprias palavras de Marley?

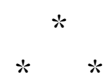

Velhos piratas sim rouba eu/Vende eu aos barcos de mercadores. Temos aqui Marley numa evocação pertinaz em que proclama o brotar de futuras gerações e nos pede que juntemos a nossa voz em "canções de liberdade". Contudo, as imagens e as emoções por trás da música doem, e doem literalmente. Em fundo, tudo é fogo e mutilação, o pavor da submersão, insolações, e trabalho de partir a espinha por entre a folhagem cortante da cana-do-açúcar. Depreendemos o orgulho no passado, mas sabemos que ele cavalga mares agitados em que pereceram corpos africanos. 
Na sua obra clássica The Souls of Black Folk (As almas da gente negra), W. E. B. Du Bois falou nas "Canções de lamento" - "The Sorrow Songs". Nesses velhos espirituais negros vemo-nos confinados à memória e ao luto, às modulações já quase esquecidas de línguas nativas erguidas colectivamente como escudos contra o desespero suicida. Dizer, cantar, delinear a perda do negro sob a forma de "canções de lamento" é, nas palavras de Du Bois, uma casa-abrigo de redenção. Mas os factos objectivos da canção redentoramente "tardia", materiais e inelutáveis como são, mantêm-se: velhos piratas sim rouba eu / Vende eu aos barcos de mercadores! Daí que nos imaginemos a recuar no tempo, para, dois séculos antes de Marley e Du Bois, ouvir a voz cosmopolita da autobiografia africana contar, in media res:

A primeira coisa a saudar-me os olhos quando cheguei à costa foi o mar, e um barco negreiro aí ancorado, à espera da carga. Tal encheu-me de espanto, que logo se converteu em terror, quando fui levado para bordo. Fui de imediato agarrado e empurrado por alguns da tripulação, para ver se eu era são; e então me convenci que havia sido lançado para um mundo de espíritos maus e que estes me iam matar. A pele deles, tão diversa da nossa, e os longos cabelos e a língua que falavam (muito diversa de quantas já ouvira) mais confirmaram essa minha convicção. Na verdade, tais eram os horrores do que na altura via e os meus medos que, se dez mil mundos tivesse de meus, de bom grado a todos os daria para trocar minha condição pela do mais miserável escravo da minha terra. Quando, no barco, olhei em meu redor, e vi uma grande fornalha de cobre que fervia e uma multidão de negros da mais variada estirpe acorrentados uns aos outros, cada um em seu rosto expressando desânimo e dor, não mais duvidei do meu destino; e, completamente tomado de horror e angústia, caí imóvel, desmaiado, no convés. (Equiano, 1995: 53-54)

Este é o relato de Olaudah Equiano recordando com horror o momento de ser levado, ainda pré-adolescente, para um entreposto costeiro de escravos de África. Equiano foi apenas um entre mais de doze milhões de africanos que, ao longo de quatro séculos, foram vítimas do Comércio Transatlântico de Escravos, uma inimaginável rede expansiva de natureza mercantilista, económica, religiosa, sócio-política e cultural.

Quem inicialmente arrancou Olaudah Equiano (cuja autenticidade enquanto autobiógrafo deste comércio suscita, hoje em dia, algumas suspeitas por parte dos estudiosos) e a irmã do povoado onde viviam com a família, não foram "piratas" europeus (Carretta, 2005). Pelo contrário, foram raptados por outros africanos: 
Um dia [escreve Equiano] [...] quando a nossa gente tinha saído toda para o trabalho, como de costume, e eu fiquei sozinho com a minha irmã a tomar conta da casa, dois homens e uma mulher saltaram os muros e num instante agarraram-nos a ambos e, sem nos darem sequer tempo de gritar ou resistir, taparam-nos as bocas e fugiram connosco para o bosque mais próximo. (Equiano, 1995: 47)

Meses após, e depois de, sempre pela mão de africanos, ter trocado várias vezes de meio de transporte e de amo, e de ter sido para sempre separado da família, Equiano chega ao abjecto momento do entreposto, já descrito acima.

O comércio esclavagista, uma rede multinacional que ia desde raptos à pirataria e a movimentos migratórios, estendia-se ao interior do continente a partir do litoral, alastrando por sua vez daqui também a toda a bacia do Atlântico. O comércio situava-se na intersecção dos têxteis provenientes de África com o rum das ilhas do açúcar, as armas de fogo da Europa, as espadas de Inglaterra, o caurim da Costa do Ouro, e incontáveis milhões de libras esterlinas de Liverpool.

Não restam dúvidas de que a escravatura coexiste com a vida humana desde que o homem deixou de andar a quatro. O sítio da New Internationalist (uma organização e revista de modelo cooperativo dedicados à observação das questões da pobreza e da desigualdade globais) diz-nos que

a escravatura começou com a civilização. Para as populações de caçadores-colectores, possuir escravos seria um luxo incomportável, uma vez que não haveria alimento disponível para todos. Com o alastramento das práticas de cultivo, os vencidos em guerra passaram a poder ser tomados como escravos. A escravatura ocidental conta já 10.000 anos e provém da Mesopotâmia, o actual Iraque, onde um escravo do sexo masculino valia um pomar de tâmaras. As escravas tinham procura para a prestação de serviços sexuais, ganhando a liberdade por morte do seu senhor. (Brief History, 2001)

Porém, a moderna economia do Comércio Transatlântico de Escravos não pode ser vista como um simples prolongamento dos textos apologéticos de teor humanitário e pastoril sobre as práticas agriculturalistas anteriores à nossa era, numa linha que passaria ainda por senadores romanos ou, no caso de Equiano, por esclavagistas africanos que submetiam à servidão os prisioneiros feitos em guerras tribais de incidência local. Mais do que um descendente ou herdeiro directo de uma antiguidade da escravatura, o Comércio Transatlântico de Escravos representa e opera, exactamente, uma ruptura com o que antes se conhecia da escravatura. Na sua brutalidade 
crua e no seu deve-e-haver global, ele vem instituir, economicamente e literalmente, o mundo moderno. As principais viragens que consigo traz no sentido da modernidade são de tipo tão marcadamente económico, psicológico, jurídico e político como são de tipo tecnológico e religioso. São estes os factos puros e duros dessa longue durée a que nós, nesta nossa era académica, tão simpaticamente chamamos "Modernismo Inicial" ou da primeira fase.

O comércio global é tão venerável quanto a agricultura mesopotâmica e a epopeia homérica. No entanto, o tipo de trocas específicas que caracterizou o comércio transatlântico confere às suas redes, mecanismos, justificações, motivações e objectivos um cunho que é totalmente singular do ponto de vista comercial e assustador do ponto de vista étnico. E essa candente diferença passa directamente pelo açúcar, numa relação que tem tanto de linear como de fantástico. O cenário é uma via pública da Londres do século XVIII. Acompanhado de William Pitt, o Primeiro, o rei George observa quem passa. Reparando numa carruagem de nobres proporções e decorada a folha de ouro e filigrana, rodeada de criados e puxada por vários cavalos da melhor raça, o rei pergunta ao seu ministro: "Como ganhou este homem a sua fortuna?” Ao que Pitt responde: "Açúcar, Vossa Majestade”. E torna o rei, com espanto: "Açúcar? Assim tanto açúcar, Pitt?”. Assim tanto açúcar, de facto.

À adopção de sistemas de crença específicos conjugados com a selecção de culturas, o lucro, e modos de produção de açúcar deu-se, colectivamente, a designação de "Acordo Mediterrânico". Na produção de açúcar, o lucro estava dependente da existência de uma imensa quantidade de trabalho forçado. O trabalho forçado não é senão uma economia de roubo, uma "pirataria doce". A utilização do trabalho forçado em grande escala e de uma forma rentável deu origem à plantação como espaço de produção e ao trabalho em rancho como modo dessa produção. Por volta dos princípios do século XVII, e naquele que constitui o primeiro exemplo altamente rentável do seu género, a economia da plantação do açúcar chegou a Bengala, passando daí às "ilhas do açúcar", na região das Antilhas.

Aqui entra em cena a ética material dos primórdios da modernidade. Igreja e Estado tornam-se apoiantes cúmplices dessa economia baseada no comércio do açúcar: considerando as populações indígenas do chamado "Novo Mundo" - os índios - inadaptados e inadaptáveis ao trabalho forçado, o padre Bartolomé de Las Casas afirma que a população nativa da América deve ser incluída entre o "povo de Deus". Onde haveriam, então, os colonos de ir buscar essa maciça abundância de mão-de- 
-obra necessária à produção do açúcar? Eis o que, a propósito, escreve o historiador Peter Wood:

Desde o início que a alternativa da mão-de-obra africana se apresentou como alternativa plausível. Ela afigurava-se natural aos olhos dos colonos das Índias Ocidentais, interessante aos dos da Europa Ocidental, e vantajosa para ambos. Dado que os africanos provinham de longe, a sua exploração não colocava os sérios problemas diplomáticos e estratégicos suscitados pela mão de obra ameríndia, e contudo as suas fontes nas Caraíbas encontravam-se mais próximas e os respectivos custos de transporte eram mais baixos do que os dos trabalhadores brancos. Ao contrário do servo branco, o negro podia ser mantido por períodos ilimitados, não havendo possibilidade de as eventuais denúncias relativas a maus tratos ou a arbitrariedades contra si cometidas chegarem às suas terras ou afectarem o constante influxo de escravos. (Wood, 2003: 228)

No seu estudo clássico Sugar and Slaves ("O açúcar e os escravos"), o historiador Richard Dunn capta, com notável labor arquivístico, as condições, as ilegalidades e os protocolos do açúcar global, a que chama "selváticos", "de fronteira", "piratas" e "rapaces" (Dunn, 2000). Segundo este autor, o açúcar tornou a colonização uma necessidade. Ele gerava lucros sumptuosos e enormes fortunas. Era singularíssimo nas suas exigências, impondo a utilização de um grande número de trabalhadores durante todo o ano, sem excepção. Por sua vez, as plantações de açúcar haveriam de levar também à produção, em contexto colonial, do tabaco, do arroz, do anil e do café.

Em Portugal, os bispos tinham escravos e sancionavam a escravatura. Em Roma, um papa foi visto num dia de Verão, na parte de fora da cidade, "repartindo" a riqueza de Deus - leia-se, distribuindo cem escravos africanos que recentemente recebera em oferenda. $\mathrm{Na}$ Espanha, rainhas referiam-se aos seus "queridos" súbditos do Novo Mundo, ao mesmo tempo que chamavam aos negros de África gente pagã, para quem a "escravidão cristã" era o que melhor servia. Na Inglaterra e suas colónias americanas, Anglicanos e Quakers, subscritores da Declaração da Independência e pregadores às bateladas, davam graças ao senhor por o Comércio de Escravos haver trazido até à América as "almas pagãs", para purificador castigo destas (enquanto, como é óbvio, iam aumentando prodigiosamente as suas contas bancárias). Fizeram-se, assim, grandes fortunas. E deste modo, banqueiros e traficantes negreiros, sócios ocultos e membros da nobreza, gente religiosa e aventureiros, foram, todos eles, viciosamente aliados nessa selvática deportação de corpos negros a que se chamou Passagem Atlântica, 
uma travessia marítima feita de ossadas e de carnificina, a caminho dos trabalhos forçados. Oh "viagem pela morte / até à vida nestas praias!" (Hayden, 1997: 1505).

A questão a sublinhar aqui é que o Comércio Transatlântico veio alterar de forma irreversível as ideologias nacionais, a dinâmica das populações, os modos de produção, e as definições vigentes de raça e de resistência. E que é o modernismo senão irreversibilidade? O homem deixou de ser um fim em si mesmo para ser um meio mercadorizado... um meio, de facto e de direito, para chegar a meios e a fortunas mais amplos. E os africanos - os intermediários do continente, como os raptores de Equiano e sua irmã foram peças indispensáveis na lógica de todo este comércio.

Todos se deixaram consumir pelo deve e haver... e pela fungibilidade (essa conversão de uma coisa em outra) que transmutava os homens em dinheiro. Pois que é mais essencial ao modernismo do que a fungibilidade? Ian Baucom, autor do recente Spectres of the Atlantic ("Espectros do Atlântico"), faz notar que uma transvaloração assim eficaz, capaz de transformar verdadeiros seres humanos em unidades de valor segurável passíveis de ser transaccionadas no interior de um sistema global de crédito e de letras bancarias, terá representado, em última análise, o efeito pleno do Acordo Mediterrânico.

$\mathrm{Na}$ esteira de Baucom, revisitemos o incidente histórico passado com o navio negreiro Zong, que zarpou de Liverpool. Financiado pela mais poderosa elite da cidade, o navio fez-se ao mar a caminho do porto de Kingston, na Jamaica, completamente carregado com cerca de 470 africanos cativos. Em 29 de Novembro de 1781, o comandante, não tendo conseguido aportar à ilha da Jamaica e vendo-se com muitos escravos enfermos e as reservas de água a esgotar-se, tomou a decisão de lançar borda fora 134 cativos. A morte de escravos a bordo teria sido considerada "mortalidade geral", não sendo, por isso, uma perda recuperável. Mas como "perda média geral", a carga já poderia ser objecto de seguro. Os proprietários e os financiadores do navio apresentaram a questão da sua "perda" aos tribunais ingleses, sendo-lhes atribuída uma quanta superior a 15.000 libras a título de compensação pela "carga" perdida. A decisão foi, posteriormente, revogada, uma vez que a perda se não ficara a dever a "Fortunas de Mar".

Tais são os meandros económicos deste comércio.

Mais tarde, os proprietários do Zong iriam ter um papel fundamental na construção de um edifício novo para a Bolsa de Liverpool. Que singular símbolo haveria de ser ostentado no baixo-relevo mais altaneiro deste monumento ao comércio? Mas é claro!, nada seria mais apropriado do que circundar a coroa do edifício com cabeças esculpidas de "Pretos da Guiné". 
Chegarão as canções - perguntamos nós - para redimir toda esta pirataria global?

Poderão as viagens pela morte ser alguma vez redimidas, quando há que operar uma mudança de paradigma pelo menos tão global e tão monumental como o que originou o Comércio Transatlântico de Escravos?

Quais as consequências desse comércio nos Estados Unidos? E que tem esta história a ver com uma visão do Sul dos Estados Unidos no novo milénio?

Primeiro que tudo, a economia das plantações saldou-se por um desastre para a biodiversidade. Quanto a isto, não é preciso estar com grandes explicações. Referindo-se à plantação ficcional a que deu o nome de Sutpen's Hundred, Faulkner descreve, com mais eloquência do que qualquer outro cronista do Sul, a devastação causada a tudo quanto era "nativo" pela mão-de-obra roubada (aqueles "pretos selvagens", nas palavras do escritor). Flora, fauna, vales, colinas, rios (até o poderoso Mississipi) totalmente alterados, exauridos, destruídos, derrubados, arrasados pela necessidade de converter uma paisagem natural nativa num centro agrícola gerador de lucros.

Quando o período da primeira Reconstrução ${ }^{3}$ chegou ao seu breve termo, os campos de prisioneiros e o sistema de aluguer de mão-de-obra dos presidiários, aliados a outros factores como a exploração da terra pelo sistema de rendeiros e meeiros ${ }^{4}$ e uma cultura generalizada de violência do branco contra o negro, tornaram a agricultura do Sul praticamente sinónimo da palavra encarceramento. Hoje em dia, é no Sul que se está a dar a maior expansão do complexo industrial prisional privado de todos os Estados Unidos. Com o seu salário médio inferior a dois dólares por dia, as prisões constituem, actualmente, um arquipélago de mão-de-obra barata, onde há desde corpos encarcerados negros e morenos ${ }^{5}$, ocupados em trabalho de "assistência a clientes" para grandes empresas de dimensão global, até mulheres negras e morenas empregues na confecção de blue jeans para marcas famosas. No Sul, o Acordo Mediterrânico transmutou-se de mãode-obra roubada em mão-de-obra encarcerada. Todas as semanas, o complexo industrial prisional privado colhe lucros (globais) imensos trancando à chave o "outro" indesejável, ao mesmo tempo que lhe explora o corpo e o trabalho. O referido complexo constitui um resquício perverso da primeira ruptura global do modernismo, não podendo ser cabalmente entendido senão em termos históricos.

\footnotetext{
3 Período imediatamente posterior à Guerra da Secessão, em que o Norte vitorioso ocupou militarmente o Sul do país. [N. do T.]

4 "Tenant farming" e "sharecropping", respectivamente. Em ambos os sistemas a propriedade cultivada é arrendada, com a diferença de que, no Segundo, o agricultor tem que descontar do valor da colheita o crédito ou adiantamentos recebidos em sementes, alfaias, habitação, etc. [N. do T.]

${ }^{5}$ Da população afro-americana e hispânica, respectivamente. [N. do T.]
} 
Como W. E. B. Du Bois afirmou, "Tal como vai o Sul, assim vai a nação”. A actual realidade dos estados abaixo da linha Mason-Dixon aponta para a necessidade de uma nova iniciativa visando os Estudos sobre o Sul, centrados, precisamente, no Sul do país. Há, nomeadamente, três fenómenos que acentuam essa necessidade urgente: o fenómeno da imigração, o domínio das economias locais por parte das grandes superfícies industriais, e o crescimento demográfico, cuja rapidez se faz hoje sentir da Virginia até Pensacola e da Carolina do Norte até ao Mississipi.

Com as suas práticas e filosofia exploradoras, anti-sindicais, politicamente conservadoras, e gigantescamente globais, a cadeia de lojas Wal-Mart é o exemplo mais gritante do devastador impacto da globalização sobre comunidades menos prósperas. A propaganda empresarial da Wal-Mart retrata as suas lojas como sendo o autêntico céu e porto de abrigo da gente oprimida e sem recursos. Contudo a verdade é que a Wal-Mart não é senão a economia global do comércio de grandes dimensões, em que as economias de escala e os valores envolvidos levam a estatísticas tão atordoantes como esta: "Número de horas que a Wal-Mart leva a gerar um lucro de 37 milhões de dólares: 31" (Institute Index, 2005).

Muitas empresas de dimensão global optaram por estabelecer as respectivas sedes no Sul, de maneira a poderem explorar a mão-de-obra barata, as tradições anti-sindicais, e um racismo agudo que ainda espreita nos corações e nas mentes de uma grande parte do eleitorado sulista. O Sul proporciona um exemplo interno de globalização que, do ponto de vista económico, constitui um autêntico dilema para quem se quer progressista. Com efeito, como dizer a um pai negro, solteiro e com dois empregos, que vá comprar as roupas do filho a lojas como a Nordstrom e a Hecht's, quando os preços da Wal-Mart são sempre tão baixos?

Dos quinze estados norte-americanos com crescimento mais acelerado, seis ficam no Sul. Assiste-se presentemente ao rápido surgimento de uma nova realidade demográfica sulista, constituída principalmente por imigrantes vindos do México e da América Central: "Dos 10 estados com a mais elevada entrada de hispânicos, seis ficam no Sul: Georgia, Carolina do Norte, Kentucky, Carolina do Sul, Virginia e Alabama” (Hesse, 2003).

Deste modo, os estudiosos que se afadigam a buscar definições para o modernismo e para as dinâmicas da "nação", da "imigração", e do "lugar da cultura”, dispõem de um laboratório aqui ao pé, à mera distância de um voo de avião. Faulkner e Du Bois sabiam que o Sul haveria de ser sempre o arauto e o índice do "Americanismo" na imaginação global. Não vejo melhor maneira de concluir esta minha reflexão sobre "ruptura", "globalização", "modernismo" e o Sul do que com a seguinte observação retirada 
de um dos ensaios do já mencionado número especial da revista American Literature intitulado "O Sul Gobal":

[Existe uma premente] necessidade de pensar a natureza e a geografia do Sul como sendo, quando muito, provisórias e relacionais, como espaços que vão variando conforme se vão atravessando fronteiras e que, por efeito desse processo, se vão fortalecendo. Tal significa também que necessitamos de reorientar os estudos sobre o Sul, desviando-os do eixo "nós vs. eles, azul vs. Cinzento" " de forma a podermos pensar esse mesmo Sul de uma maneira mais ampla e a podermos teorizar o seu estatuto como um ponto-charneira entre as Américas. Há que pensar em zonas, não em fronteiras (McPherson, no prelo).

A esses estudos sobre o Sul, assim reorientados, talvez se possa dar o nome genérico de "canções de redenção".

Um dos subgéneros musicais mais populares ouvidos hoje em dia em todo o mundo dá, precisamente, pelo nome de "Dirty South". Trata-se de um tipo de "hip hop" em que se misturam, de um modo surpreendente, o pulsar das cordas do baixo, vocalizações incisivas, sons vintage de sintetizador, entoações de "gospel" negro, "riffs" de blues tocados em harmónica, e "leads" de guitarra eléctrica tipicamente sulistas, tudo isto comercializado a uma velocidade de produção vertiginosa e apoiado numa publicidade de encher os olhos e os ouvidos. Quem não está a par de nomes como os OutKast, Goodie Mob, Master P, Mystikal, Nelly, Missy Elliott, Lil' Jon, Luther Campbell, Timbaland, T.I., e outros do género deste "Durrrty south" emergente, o mais provável é também não estar preparado para se dedicar por inteiro ao projecto de leitura e escrita de "canções de redenção" de teor académico, americanas, para um futuro global. E isso equivale a dizer que quem não ouviu, ao longo destes últimos anos, as canções populares negras do Sul (que são incomensuravelmente diferentes das do Sr. Disney), dificilmente escutará ou compreenderá exactamente aquilo que hoje se pode definir como americano ou como moderno.

Depois de Coimbra, a etapa seguinte foi Lisboa, onde os jacarandás explodiam em flor por todo o lado. De um empório de música megaglobal situado numa das largas alamedas da cidade chega o latejar dos acordes de "The Way You Move”, dos OutKast. E eu penso em Faulkner.

Tradução de João Paulo Moreira

\footnotetext{
${ }^{6}$ Respectivamente as cores dos uniformes dos exércitos do Norte e do Sul, na Guerra da Secessão.
} [N. do T.] 
$64 \mid$ Houston Baker, Jr

\section{Referências bibliográficas}

Baucom, Ian (2005), Spectres of the Atlantic: Finance Capital, Slavery, and the Philosophy of History. Durham, NC: Duke UP.

'A Brief History of Slavery' (2001), New Internationalist, 337 (http://www.newint.org).

Carretta, Vincent (2005), Equiano, the African: Biography of a Self-Made Man. Athens, Georgia: University of Georgia Press.

Dunn, Richard S. (2000), Sugar and Slaves: Rise of the Planter Class in the English West Indies, 1624-1713. Chapel Hill, NC: University of North Carolina Press.

Equiano, Olaudah (1995), The Interesting Narrative of the Life of Olaudah Equiano. Org. Robert J. Allison. Boston: Bedford-St. Martin's.

Hayden, Robert (1997), "Middle Passage”, in Henry Louis Gates, Jr. (org.), Norton Anthology of African American Literature. Nova Iorque: Norton, 1501-1505.

'Institute Index: Tax Dollars at Work' (2005), Facing South. Blogging for a Progressive South, 107 (http://www.southernstudies.org/news/news.asp?d=20050413).

Marley, Bob (2002), "Redemption Song" (http://www.bobmarley.com/songs/songs. cgi? redemption).

McPherson, Tara (no prelo), 'On Wal-Mart and Southern Studies', American Literature.

Niesse, Mark (2003), "Hispanic Migrants Head to South", CBS News, 18 Set. (http:// www.cbsnews.com/stories/2003/09/18/national/main573946.shmtl).

Wood, Peter H. (2003), "Black Labor - White Rice", in Gad Heuman; James Walvin (orgs.), The Slavery Reader. New York: Routledge, 224-244.

Zurara, Gomes Eanes de (1937), Crónica do descobrimento e conquista da Guiné. Org. José de Bragança. Vol. 1. Porto: Livraria Civilização Editora. 